\title{
In vitro anti influenza virus activity, antioxidant potential and total phenolic content of twelve Iranian medicinal plants
}

Mohammad-Taghi MORADI, Ali KARIMI, Zahra LORIGOOINI, Batoul POURGHEYSARI, Somayeh ALIDADI, Leila HASHEMI

\begin{abstract}
The emergence of medicine resistance strains of influenza A viruses to the chemical drogs lead to the development of alternative herbal compounds that inhibit the virus replication. Therefore, the aim of this research was to investigate in vitro anti-influenza A viruses activity, antioxidant potential, total phenolic, and flavonoid content of a total of 12 hydro alcoholic crude extracts obtained from 8 kinds of medicinal plants. Antiinfluenza A viruses activity of the extracts was investigated by the using of MDCK cell line and MTT (3-[4,5-dimethylthiazol2-yl]-2,5-diphenyltetrazolium bromide) method. Both $50 \%$ inhibitory concentration $\left(\mathrm{IC}_{50}\right)$ and $50 \%$ cytotoxicity concentration $\left(\mathrm{CC}_{50}\right)$ of the extracts were identified using regression analysis. The antioxidant activity, total phenol, and flavonoid content of the extracts were determined using 2,
\end{abstract}

2-diphenyl-1-picrylhydrazyl (DPPH) assay, Folin-Ciocalteu method, and aluminum chloride colorimetric method, respectively. The results demonstrated that there was high activity against influenza virus for Peganum harmala L., Equisetum arvense $\mathrm{L}$., and Punica granatum $\mathrm{L}$, extracts with $\mathrm{IC}_{50}$ value of 9.1 (CI95\%:7.3-11.3), 6.45 (CI95\%: 4.5-9.23), and 104.5 (CI95\%: 82.8-131.8), respectively. DPPH radical scavenging activity showed that both Equisetum arvense L. and Punica granatum L. demonstrated the highest antioxidant activity with $\mathrm{IC}_{50}$ value of $6.5,6.8$ and $7.7 \mu \mathrm{g} / \mathrm{mL}$, respectively. According to the results, some of these extracts might be further analyzed to develop effective anti-influenza factors.

Keywords: Antiviral activity, medical plant, Influenza virus, Antioxidant potential
Mohammad-Taghi Moradi

Students Research Committee, Shahrekord University of Medical Sciences, Shahrekord, Iran.

Ali Karimi, Zahra Lorigooini

Medical Plants Research Center, Basic Health Sciences Institute, Shahrekord University of Medical Sciences, Shahrekord, Iran.

Batoul Pourgheysari

Cellular and molecular Research Center, Basic Health Sciences Institute, Shahrekord University of Medical Sciences, Shahrekord, Iran.

Somayeh Alidadi, Leila Hashemi

Clinical Biochemistry Research Center, Basic Health Sciences Institute, Shahrekord University of Medical Sciences, Shahrekord, Iran.

Corresponding Author:

Ali Karimi

e-mail:kakarimi42@gmail.com

Submitted / Gönderilme: 04.04.2017

Revised / Düzeltme: 06.06.2017

Accepted / Kabul: $\quad 13.06 .2017$

How to cite this article: Moradi MT, Karimi A, Lorigooini Z, Pourgheysari $\mathrm{B}$, Alidadi S, Hashemi L. In vitro Anti influenza virus activity, antioxidant potential and total phenolic content of twelve Iranian medicinal plants. Marmara Pharm J 2017; 21 (4): 843-851

\section{Introduction}

Among different kinds of viruses, one of the most common human respiratory tract pathogens that have high level of morbidity and death rate is influenza virus [1]. Segmented ribonucleic acid genome and animal reservoir cause genetic reassortment in the virus. The appearance of new human and non-human source of influenza virus with the ability to cross-species barriers creates with high rate of antigenic drift and shift; also it changes to pathogenic type in their new hosts $[2,3]$.

Currently, in order to treat anti-influenza A virus two main groups of medicines including matrix protein (M2), ionchannel inhibitors (Rimantadine and Amantadine), and neuraminidase inhibitors (Zanamivir, Oseltamivir, and Peramivir) are confirmed. On the one hand, the lack of an effective immunogenic vaccine improved against this virus; and on the other, the constant evolvement of influenza A virus causes the rapid emergence of resistance to current medicines $[4,5]$. Therefore, it is essential to make the new 
and efficient anti-influenza medicines in order to treat resistant forms of influenza A virus.

For a long time, plants have been used as remedies and have shown the ability to synthesize a wide range of compounds. Therefore, in order to identify the probable sources of herbal medicines several plants are being gathered and examined [6-11]. Besides, different screening experiments have been performed on these plants to isolate the agents with antiviral activity [12-15]. In some cases of these herbal medicines there has been a development into therapeutic agents and they have had promising outcomes.

Iran with rich and diverse local health tradition is endowed valuable plant genetic source. In order to verify their efficacy and safety, more detailed survey and documentation of plants used in local health traditions and ethnopharmacological evaluation might lead to the development of invaluable herbal medicines or isolation of compounds of therapeutic value. Therefore, this research was aimed to investigate 12 species of plants for antiviral activity against influenza A virus.

\section{Matrials and methods}

\section{Plant collection and extraction}

Different parts of 12 medicinal plants belonging to 8 different families (Table I) were tested for their antiviral activity. The selected plants were provided from market of medicinal plants from Shahrekord, Iran (southwest of Iran) and were identified by the Dr. Lorigooini according to the Flora of Iran. Voucher specimens of the plants were deposited in the herbarium of the Medical Plants Research Center, Shahrekord University of Medical Sciences, Iran (Table 1).

Plants were dried, powdered, and extracted using maceration method. The plant material was dissolved in $70 \%$ ethyl alcohol and kept at room temperature (RT) for $96 \mathrm{~h}$. After that, the mixture was filtered and concentrated under nearly vacuum pressure at $40^{\circ} \mathrm{C}$ by using rotary evaporator. In order to further use, the extracts were kept in sterile bottles and under refrigerated conditions. In the following, the extracts were suspended at $37^{\circ} \mathrm{C}$ in dimethylsulphoxide (DMSO) to give a stock solution of $10 \mathrm{mg} / \mathrm{mL}$, dissolved in culture medium, filtered and stored $\left(4^{\circ} \mathrm{C}\right)$ until used. The little percentage of DMSO present in the wells (maximal 0.2\%) has no effect on the results of the experiments [16].

\section{Determination of the free-radical scavenging activity}

In 2,2 diphenyl-1-picrylhydrazyl (DPPH) method described by Moon and Terao with some modifications, the freeradical scavenging activity was measured [17]. Briefly, different amounts of the extracts and methanol were added to a solution of $0.3 \mathrm{mg} / \mathrm{mL}$ methanolic solution of DPPH in order to make a total volume of $3.0 \mathrm{~mL}$. After incubation for $15 \mathrm{~min}$ at RT, the absorbance was measured at $517 \mathrm{~nm}$ using UV-VIS pectrophotometer (UNICO 2100: USA).

Table 1. Ethnobotanical data of selected medicinal plants

\begin{tabular}{llllllc}
\hline NO & Family & Plant name & Part used & Local name & Common name & Voucher \\
\hline 1 & Apiaceae & Ferula gummosa Boiss & gum & Barigeh & Galbanum & MPSKUMS-650 \\
2 & Apiaceae & Ferula assa-foetida $L$ & Leaves & Anghozeh & Asafoetida & MPSKUMS-470 \\
3 & Apiaceae & Prangos ferulacea $($ L. $)$ & gum & Jashir & Ribbed Cachrys & MPSKUMS-320 \\
\hline 4 & Berberidaceae & Berberis integerrima Bunge & root & Zereshkekoohi & Barberry & MPSKUMS-512 \\
5 & Equisetaceae & Equisetum arvense L. & Aerial parts & Domeasb & Horsetail & MPSKUMS-516 \\
\hline 6 & Lamiaceae & Ziziphora clinopodioides Lam. & Aerial parts & Kakooti & - & MPSKUMS-253 \\
\hline 7 & Lamiaceae & Thymus daenensis Celak. & Aerial parts & Avishandenaei & thyme & MPSKUMS-248 \\
\hline 8 & Lamiaceae & Hyssopus officinalis L. & flowers & Zofa & hyssop & MPSKUMS-177 \\
\hline 9 & Lythraceae & Punica granatum L. & Peel fruits & Anar & Pomegranate & MPSKUMS-316 \\
\hline 10 & Pteridaceae & Adiantum capillus-veneris L. & Leaves & Parsiyavash & maidenhair & MPSKUMS-131 \\
\hline 11 & Rosaceae & Crataegus azarolus L. & Leaves & Zalzalak & Hawthorn & MPSKUMS-499 \\
\hline 12 & Zygophyllaceae & Peganum harmala $L$ & Seed & Espand & Syrian rue & MPSKUMS-188 \\
\hline
\end{tabular}


High absorbance of the reaction mixture indicated low free radical scavenging activity. Butylated hydroxytoluene (BHT) was used as reference standard. Inhibition of free radical by DPPH was calculated as follows: Antiradical activity (\%) = (Acontrol - Asample)/Acontrol $\times 100$. The $\mathrm{IC}_{50}$ value was defined as the amount of antioxidant necessary to reduce the initial DPPH concentration by $50 \%$; and was calculated based on linear regression of plots of the percentage antiradical activity against the concentration of the tested compounds [18]. The experiment was performed in triplicate and the results had average values.

\section{Determination of total phenolic content}

In each plant extract, the total phenolic content was determined using Folin-Ciocalteu method with some modifications made by Asadi-Samani and coworkers [19]. Briefly, $0.1 \mathrm{~mL}$ of the diluted sample was added to $0.5 \mathrm{~mL}$ of $10 \%(\mathrm{v} / \mathrm{v})$ Folin-Ciocalteu reagent and kept at room temperature (RT) for 3-8 min. Subsequently, $0.4 \mathrm{~mL}$ of $7.5 \%$ $(\mathrm{w} / \mathrm{v})$ sodium carbonate solution was added to the mixture. After being kept in total darkness for $30 \mathrm{~min}$., the absorbance of the reaction mixture was measured at $765 \mathrm{~nm}$ using a UV-VIS spectrophotometer (UNICO 2100: USA). Then, amounts of total phenolic were calculated by the application of gallic acid calibration curve. The results were expressed as gallic acid equivalents (GAE) g/g of dry plant matter.

\section{Determination of total flavonoid content}

With the same previously mentioned method, the total flavonoid content of each plant extract was measured [20]. Independently, $0.5 \mathrm{~mL}$ of diluted plant material was mixed with $1.5 \mathrm{~mL}$ of methanol, $0.1 \mathrm{~mL}$ of $10 \%(\mathrm{w} / \mathrm{v})$ aluminum chloride, $0.1 \mathrm{~mL}$ of $1 \mathrm{M}$ potassium acetate, and $2.8 \mathrm{~mL}$ of distilled water. Based on the incubation at room temperature (RT) for $40 \mathrm{~min}$, the absorbance of the reaction mixture was read at $415 \mathrm{~nm}$ by the application of a UV-VIS spectrophotometer (UNICO 2100: USA). The results were presented in mg of Rutin equivalents of dry plant matter in comparison with the standard curve; which was made in the same condition.

\section{Cell and Virus}

Madin Darby Canine Kidney (MDCK) cells were grown in Dulbecco's Modified Eagle's Medium (DMEM; Gibco, USA), supplemented with 10\% fetal bovine serum (FBS; Gibco,
USA) and $1 \%$ Pen/Strep (Gibco, USA) at $37^{\circ} \mathrm{C}$ in a $5 \% \mathrm{CO} 2$ atmosphere and humidified incubator.

MDCK cell line and Influenza A virus (A/ Iran/12/2014(H1N1)) was obtained from Influenza Unit, Pasteur Institute of Iran. Before the viral infection, MDCK cells were washed twice with phosphate buffered saline (PBS) and cultured in virus growth medium containing DMEM with penicillin/streptomycin, $2 \mu \mathrm{g} / \mathrm{mL}$ trypsin TPCK (SigmaAldrich, USA), and $0.3 \%$ bovine serum albumin (BSA, Gibco, USA).

\section{Virus titration}

A standard $50 \%$ tissue culture infectious doses $\left(\mathrm{TCID}_{50}\right)$ method was applied for virus titration [21]. When, 90\% confluent MDCK cells were prepared in 96 well plates, the cell culture medium was aspirated and washed twice with phosphate-buffered saline (PBS). Then, $200 \mu \mathrm{L}$ of a series of 10 -fold dilutions of virus in virus growth medium containing DMEM with $0.5 \mu \mathrm{g} / \mathrm{mL}$ trypsin TPCK was added into the wells and left to incubate for 2 days. Consequently, $50 \mu \mathrm{L}$ of culture medium were taken from each well and transferred to a U-bottomed 96-well plate for hemagglutination experiment [22]. TCID $_{50}$ which was calculated based on the method of Reed and Muench [23].

\section{Screening of antiviral activity}

The antiviral activity of each plant extract was screened in 96-well culture plates by measuring the reduction of the viral cytopathic effect (CPE) [24]. Briefly, confluent MDCK cell monolayers were infected with $100 \mu \mathrm{L}\left(100 \mathrm{TCID}_{50}\right)$ of virus suspension and incubated at $37^{\circ} \mathrm{C}$ for about one hour to allow virus adsorption and then the virus was removed and the cells were treated with 25,50 and $100 \mu \mathrm{g} / \mathrm{mL}$ of each extracts [24] supplemented with $2 \mu \mathrm{g} / \mathrm{mL}$ TPCK and $0.3 \%$ BSA $\left(200 \mu \mathrm{L} /\right.$ well). The plates were incubated at $37^{\circ} \mathrm{C}$ in a humidified $\mathrm{CO}_{2}$ atmosphere until $90 \%$ of viral $\mathrm{CPE}$ in the control virus was reached. The reduction of viral $\mathrm{CPE}$ was determined by measuring cell viability by the tetrazolium salt MTT [3-(4,5-dimethylthiazol-2-ol)-2,5diphenyltetrazoliumbromide), (Sigma, USA)] colorimetric assay.

Results of the screening were expressed as positive (+), reduction of viral $\mathrm{CPE}$ was higher than 50\% at all three concentrations tested, negative $(-)$ without protection at all three concentrations tested, $(++/-)$ reduction of viral 
CPE was higher than $50 \%$ at 100 and $50 \mu \mathrm{g} / \mathrm{mL}$, and $+/--$ reduction of viral CPE was higher than $50 \%$ only at $100 \mu \mathrm{g} /$ $\mathrm{mL}[24]$.

\section{Cytotoxicity Experiment}

The cytotoxic effect (CPE) of the positive extracts was determined before the investigation of anti-influenza A virus activity. MDCK cells were seeded onto 96-well plates with a concentration of 15000 cells/well with final volume of $100 \mu \mathrm{L}$ per well. After incubation at $37^{\circ} \mathrm{C}$ with $5 \% \mathrm{CO}_{2}$ for $24 \mathrm{~h}$, while the cell monolayer was confluent, the cell culture medium of cells aspirated and washed with PBS. Cells were incubated with $100 \mu \mathrm{L} /$ well of various concentrations of three positive plant extract (Punica granatum L., Equisetum arvense L. and Peganum harmala L.) (in DMEM), and incubated at $37^{\circ} \mathrm{C}$ with $5 \% \mathrm{CO}_{2}$ for further 3 days. Cell viability was investigated by the ability of the cells to cleave the tetrazolium salt MTT, by the mitochondrial enzyme succinate dehydrogenase that develops a formazan blue color product, and also by the procedure was followed as described earlier [25]. In sum, the supernatants were removed from the wells in this phase and $50 \mu \mathrm{L}$ of an MTT (Sigma, USA) solution ( $1 \mathrm{mg} / \mathrm{mL}$ in PBS) was added to each well. The plates were incubated for $4 \mathrm{~h}$ at $37^{\circ} \mathrm{C}$, and $100 \mu \mathrm{L}$ of DMSO (sigma, USA) was added to the wells to dissolve the MTT crystals. The plates were located on a shaker for $15 \mathrm{~min}$ and the absorbance were read on an enzyme-linked immunosorbent experiment (ELISA) reader (STATA FAX 2100, USA) at $492 \mathrm{~nm}$. Data of the study were calculated as the percentage of toxicity by the application of the following formula: toxicity $(\%)=[100-($ At/As $) \times 100] \%$, where At and As refer to the absorbance of the test substance and the solvent control, respectively [16]. Therefore, the $50 \%$ cytotoxic concentration $\left(\mathrm{CC}_{50}\right)$ was explained as the cytotoxic concentration of the crude extracts by regression Pribit model.

\section{Antiviral Experiment}

In positive extracts the antiviral activity was evaluated by inhibitory activity experiment using MTT method that described previously [16]. To test the ability of extracts to inhibit CPE of influenza virus in tissue culture, non-cytotoxic concentrations of each extracts (below the $\mathrm{CC}_{50}$ value) were applied. Confluent MDCK cells monolayer were infected with $100 \mu \mathrm{L}\left(100 \mathrm{TCID}_{50}\right)$ virus suspension and incubated at $37^{\circ} \mathrm{C}$ for about one hour to allow virus adsorption. Then, the virus was removed and the cells were treated with serial two fold dilutions from nontoxic concentration of three positive plants extract (Punica granatum L., Equisetum arvense L. and Peganum harmala L.) in DMEM supplemented with $2 \mu \mathrm{g} /$

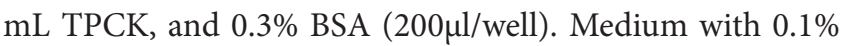
DMSO and oseltamivir (Sigma, USA) were used as negative and positive controls, respectively. The plates were incubated at $37^{\circ} \mathrm{C}$ in a humidified $\mathrm{CO} 2$ atmosphere for $48 \mathrm{~h}$. Also, cell viability was determined by the application of previously described MTT experiment; and the percentage of protection were calculated as the percentage of inhibition according to the following formula: Antiviral activity (\%)=(Atv$\mathrm{Acv}) /(\mathrm{Acd}-\mathrm{Acv}) \times 100 \%$, where Atv, Acv, and Acd are the absorbance of the test compounds in virus infected cells, the absorbance of the virus control, and the absorbance of the cell control, respectively[16]. The procedure was performed in triplicate and the $50 \%$ inhibitory concentration $\left(\mathrm{IC}_{50}\right)$ was determined by regression Pribit model. As a marker of antiviral activity, selectivity index was determined as the ratio of $\mathrm{CC}_{50}$ to $\mathrm{IC}_{50}$.

\section{Statistical analysis}

All the experiments were carried out in triplicate. The spearman's correlation test was used to determine whether the total phenolic contents and the free radical scavenging property were correlated or not. The $\mathrm{IC}_{50}$ and $\mathrm{CC}_{50}$ values were calculated by the application of dose-response analyses and related models with probit procedure using SPSS software.

\section{Results}

\section{DPPH radical scavenging activity, Total phenolic and flavonoid compounds}

Different parts of 12 medicinal plants belonging to 8 different families (Table I) were used traditionally for treatment of diseases and were tested for their antiviral activity. Their $\mathrm{DPPH}$ radical scavenging activity, total phenolic, and flavonoid contents were measured. DPPH radical scavenging activity demonstrated that the Equisetum arvense $\mathrm{L}$. and Punica granatum L. has shown the highest $\mathrm{IC}_{50}$ value $(6.5,6.8$ and $7.7 \mu \mathrm{g} / \mathrm{mL}$, respectively) in comparison with the other extracts under the investigation. The results are presented in relation to the butylated hydroxytoluene $(\mathrm{BHT})$, a reference standard that has $\mathrm{IC}_{50}$ of $25.41 \pm 1.89 \mu \mathrm{g} / \mathrm{mL}$. Besides, results demonstrated that among 12 medicinal plant extract, the Punica granatum L. (282.9), Equisetum arvense L. (262.1), and Crataegus azarolus L. (214.2) had the highest amount of 
total phenolic compounds. There was negatively significant correlation between total phenolic content and IC50 of DPPH scavenging activity values $(\mathrm{r}=-0.8472, \mathrm{p}<0.001)$. The highest amount of flavonoid (57.2) compound was observed in Punica granatum L. (57.6) and Adiantum capillus-veneris L. (Table2).

\section{Screening of antiviral activity}

Three out of 12 tested plants extract were reported to have antiviral activity at a nontoxic concentration to the used cell line against influenza virus (MDCK) (Table 2).

\section{Cytotoxicity and Antiviral Experiment}

In the present study, in vitro anti influenza activity of hydroalcoholic extracts were evaluated using MDCK cell line. According to MTT analysis and probit analysis, the $\mathrm{CC}_{50}$ value of Punica granatum L., Equisetum arvense L. and Peganum harmala L. crud extracts on MDCK cells were 55.66 (48.4-64), 639.3 (592-689.9), 122.9 (107.8-140) $\mu \mathrm{g} /$ $\mathrm{mL}$, respectively. The analysis demonstrated that the extract concentration was significantly related to the cell death $(\mathrm{P}<0.01$, Figure 1$)$.

The antiviral activity of the most promising extracts detected during the screening procedure was more evaluated in detail by the application of MTT method. MDCK cells were inoculated with 100 TCID $_{50}(100 \mu \mathrm{L} /$ well $)$ of influenza virus for $1 \mathrm{~h}$ and were treated with various doses of Punica granatum L., Equisetum arvense L. , and Peganum harmala L. crude extracts. Findings of this study showed that the more extract concentration, the more cytopathic effect (CPE) inhibition $(\mathrm{P}<0.05$, Figure 1$)$. According to Probit analysis, the extracts of Peganum harmala L., Punica granatum L., and Equisetum arvense L. had high activity against influenza virus with IC $_{50}$ values of 9.1 (CI95\%:7.311.3), 6.45 (CI95\%: 4.5-9.23), and 104.5 (CI95\%: 82.8131.8), respectively (Table 3 ). Most of these extracts had partial activity at the applied low concentration. The results demonstrated that Punica granatum L., Equisetum arvense L., and Peganum harmala L. exhibited the highest SI values (8.63, 6.12 and 13.5, respectively) against Influenza virus (Table 3).

Table 2. DPPH-radical scavenging activity $\left(\mathrm{IC}_{50}\right)$, total phenolics and flavonoid contents and Screening of antiviral activity against influenza A virus of plants extract

\begin{tabular}{|c|c|c|c|c|c|}
\hline NO & Plant name & $\begin{array}{l}\text { DPPH-radical } \\
\text { scavenging } \\
\text { activity } \\
\mathrm{IC}_{50}(\mu \mathrm{g} / \mathrm{ml})\end{array}$ & $\begin{array}{l}\text { Total phenolics } \\
(\mathrm{mg} \mathrm{GAE} / \mathrm{g})\end{array}$ & $\begin{array}{l}\text { Flavonoid content } \\
(\mathrm{mgRUT} / \mathrm{g})\end{array}$ & $\begin{array}{l}\text { Anti influenza virus } \\
\text { activity }\end{array}$ \\
\hline 1 & Peganum harmala L & 125.8 & 111.16 & 46.2 & + \\
\hline 2 & Ferula gummosa Boiss & $>1000$ & 33.26 & - & - \\
\hline 3 & Ferula assa-foetida $L$ & 396.6 & 110.4 & 51.2 & - \\
\hline 4 & Prangos ferulacea (L.) & $>1000$ & 43.17 & - & - \\
\hline 5 & Equisetum arvense $\mathrm{L}$. & 22.7 & 136.2 & 25.25 & $+/--$ \\
\hline 6 & Punica granatum L. & 10.33 & 174.9 & 60.6 & + \\
\hline 7 & Crataegus azarolus L. & 231 & 171.38 & 69.9 & - \\
\hline 8 & Berberis integerrima Bunge & 163.2 & 100.42 & 25.21 & - \\
\hline 9 & Ziziphora clinopodioides Lam. & 31.8 & 165.88 & 109.2 & - \\
\hline 10 & Thymus daenensis Celak. & 51.9 & 114.83 & 92.45 & - \\
\hline 11 & Adiantum capillus-veneris L. & 235.9 & 110.3 & 51.2 & - \\
\hline 12 & Hyssopus officinalis L. & 522.2 & 58.77 & 27.14 & - \\
\hline
\end{tabular}

The antiviral activity was tested by the reduction of viral cytopathic effect (CPE) assays.

$(+)$ positive: reduction of viral CPE higher than $50 \%$ at all three concentrations tested.

$(++/-)$ reduction of viral CPE higher than $50 \%$ at 100 and $50 \mu \mathrm{g} / \mathrm{mL}$

(+/--) positive/negative: reduction of viral CPE only at $100 \mu \mathrm{g} / \mathrm{mL}$.

$(-)$ negative: without protection at 25,50 and at $100 \mu \mathrm{g} / \mathrm{mL}$. 
Table 3. Assessment of cytotoxicity and Anti influenza virus activity of selected plant extracts by MTT assay in MDCK cell line

\begin{tabular}{cccc}
\hline Plant name & $\mathrm{CC}_{50}{ }^{\mathrm{a}} \mu \mathrm{g} / \mathrm{ml}(\mathrm{CI} 95 \%)$ & $\mathrm{IC}_{50}{ }^{\mathrm{b}} \mu \mathrm{g} / \mathrm{ml}(\mathrm{CI} 95 \%)$ & $\mathrm{SI}^{\mathrm{c}}$ \\
\hline Punica granatum L. & $55.66(48.4-64)$ & $6.45(4.5-9.23)$ & 8.63 \\
Equisetum arvense L. & $639.3(592-689.9)$ & $104.5(82.8-131.8)$ & 6.12 \\
Peganum harmala L. & $122.9(107.8-140)$ & $9.1(7.3-11.3)$ & 13.5 \\
Oseltamivir $\mu$ mol $)^{*}$ & $539.4(378.9-768.5)$ & $0.873(0.55-1.37)$ & 617.8 \\
\hline
\end{tabular}

${ }^{\mathrm{a}} \mathrm{CC}_{50}: 50 \%$ cytotoxic concentration, ${ }^{\mathrm{b}} \mathrm{IC}_{50}: 50 \%$ inhibitory concentration; ${ }^{\mathrm{c}} \mathrm{SI}$ : Selectivity index, is the ratio of $\mathrm{CC}_{50}$ to $\mathrm{IC}_{50}$; $\mathrm{CI} 95 \%$ : $95 \%$ Confidence Interval; ${ }^{\star}$ Oseltamivir was used as positive controls.
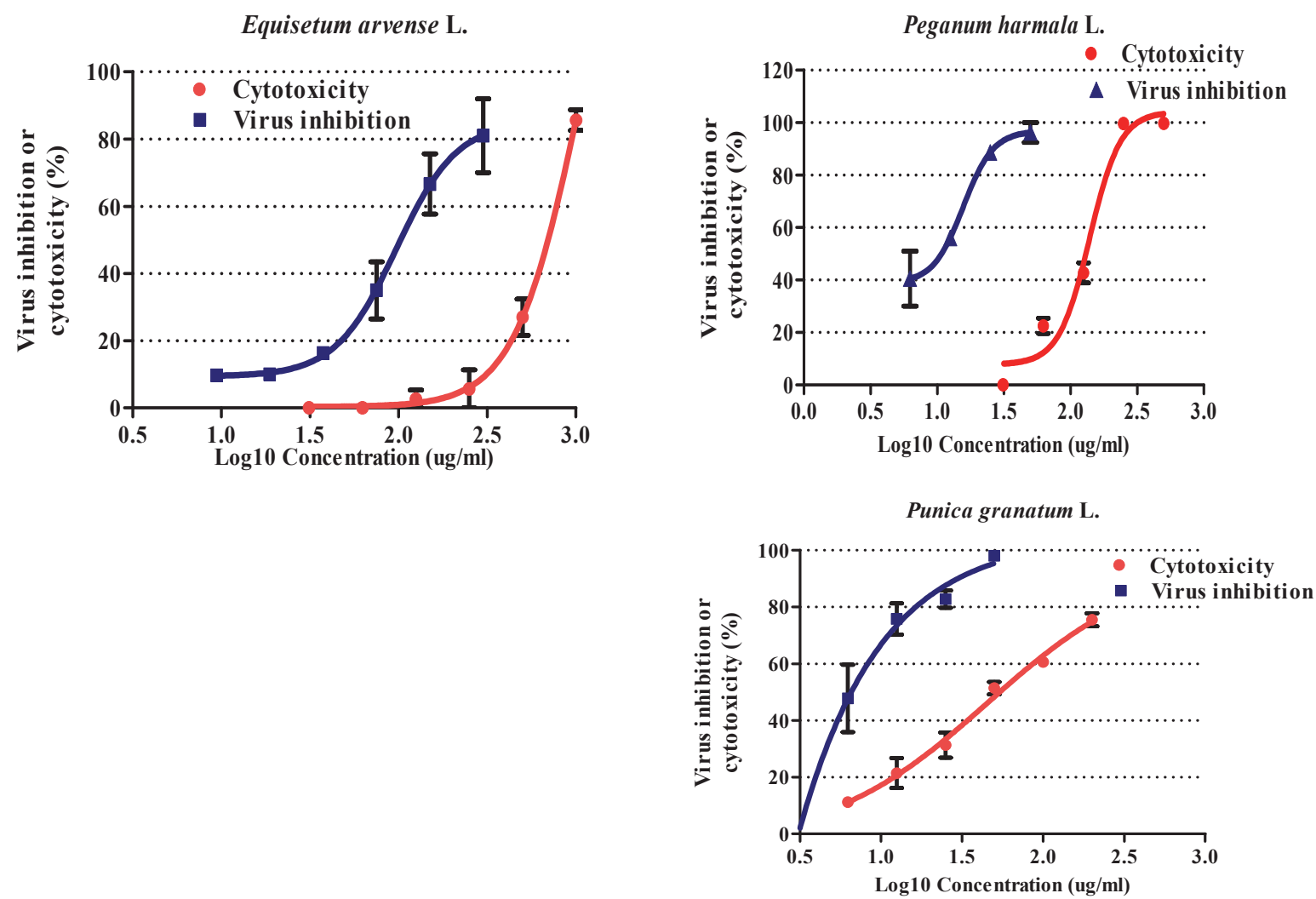

Figure 1. Anti influenza virus activity and cytotoxicity of Punica granatum L., Equisetum arvense L. and Peganum harmala L. extracts on MDCK cell lines. Confluent MDCK cells without virus or after influenza A virus infection were exposed to different concentrations of the extract for $48 \mathrm{~h}$. Cell viability was measured with MTT assay. Results are means \pm SD from three experiments.

\section{Discussion}

Initial screening of plants typically begins by using crude aqueous or alcohol extraction in order to explore their active natural products and then will be followed by various organic extraction methods [26-29]. In this study, we investigated 12 plant extracts for their anti-influenza virus activity, antioxidant potential, and total phenolic compounds.
$\mathrm{DPPH}$ radical scavenging activity showed that the $\mathrm{IC}_{50}$ of Equisetum arvense L. and Punica granatum L. extracts (6.5, 6.8 and $7.7 \mu \mathrm{g} / \mathrm{mL}$, respectively) was less than the other plant extracts under study. These results showed that the radical scavenging activity of these plants extracts were higher than BHT. The antioxidant potential and phenolic diversity in many plants have been previously reported [30,31]. In present 
study, the amount of phenolic compounds was expressed as gallic acid equivalent. Our results showed that among the 12 medicinal plants extract, the Punica granatum L. (282.9), Equisetum arvense L. (262.1), and Crataegus azarolus L. (214.2) had the highest amount of total phenolic compounds. There was a negatively significant correlation between phenolic content and $\mathrm{IC}_{50}$ values $(\mathrm{r}=-0.8472, \mathrm{p}<0.001)$. Phenolic compounds by donation of one $\mathrm{H}^{+}$cause scavenging free radicals and inhibition of macromolecules damage. In other words, in these extracts, phenolic compounds may be responsible for a part of radical scavenging activity. In other researches, a moderate correlation was found between DPPH radical scavenging and phenolic content in plant extract [32, 33].

According to Probit analysis, crude extracts of Peganum harmala L., Punica granatum L., and Equisetum arvense L. had high activity against influenza virus with $\mathrm{IC}_{50}$ values of 9.1 (CI95\%:7.3-11.3), 6.45 (CI95\%: 4.5-9.23), and 104.5 (CI95\%: 82.8-131.8) respectively. As an $\mathrm{IC}_{50}$ value of a characteristic herbal extract against infectious diseases is less than $100 \mu \mathrm{g} /$ $\mathrm{mL}$ [33], these extracts should have strong antiviral activity against influenza virus.

The antiviral activity of pomegranate extract may be associated with the presence of hydrolysable tannins and polyphenols, specifically punicalagin and gallagic acid [34].

Peganum harmala L. with some alkaloids compounds has been considered from long time ago as a herbal medicine. The pharmacochemical studies compounds of this herb include several alkaloids, $\beta$-carbolines (such as harmine, harmaline, harman and harmalol), and the quinazoline derivatives of vasicine and vasicinone [35]. It has been reported that two alkaloid compounds of the $\beta$-carbolines and the quinazoline have anti-influenza A virus activity [3638]. Therefore, the anti-influenza A virus activity of Peganum harmala L. extract used in this study could be attributed to its alkaloid components.

The Punica granatum L.peel is considered as an agro-waste but it can be a potential source of various phenolic and flavonoid compounds which shows antibacterial, antiviral, antioxidant, anti-inflammatory and antineoplastic bioactivities [39]. The anti-influenza A virus activity of this extract could be attributed to its phenolic compounds. The anti-influenza A virus activities of some extracts have been attributed to their phenolic and flavonoid compounds. Therefore, other plants having these compounds [40-44] may also have antiviral activities which worth examining.

\section{Conclusion}

Equisetum arvense L. and Punica granatum L. extracts were rich in total phenolic compounds and exhibited antioxidant activity higher than the other plants tested. Also, there was a significant correlation between phenolic content and antioxidant activity. Since Equisetum arvense L., Punica granatum and Peganium harmala L. extracts have inhibited influenza virus replication, therefore further research is needed to elucidate the active constituents of these extracts for discovering of the novel anti-influenza activity agents.

\section{Acknowledgment}

This work was supported by the Shahrekord University of Medical Science, Shahrekord, Iran (Grant No.:1750). Authors are thankful to the Director of Medical Plants Research Center and to the Deputy of Research and Technology of Shahrekord University of Medical Sciences, Shahrekord, Iran.

\section{References}

1. Nicholson KG, Wood JM, Zambon M. Influenza. Lancet 2003;362:1733-45.

2. Novel Swine-Origin Influenza A (H1N1) Virus Investigation Team, Dawood FS, Jain S, Finelli L, Shaw MW, Lindstrom S, Garten RJ, Gubareva LV, Xu X, Bridges CB, Uyeki TM. Emergence of a novel swine-origin influenza A (H1N1) virus in humans. N Engl J Med 2009;360:2605-15.

3. Cannell JJ, Zasloff M, Garland CF, Scragg R, Giovannucci E. On the epidemiology of influenza. Virol J 2008;5:422X-5.

4. van der Vries E, Schutten M, Fraaij P, Boucher C, Osterhaus A. Influenza virus resistance to antiviral therapy. Adv Pharmacol 2013;67:217-465.

5. Dapat C, Kondo H, Dapat IC, Baranovich T, Suzuki Y, Shobugawa Y, Saito K, Saito R, Suzuki H. Neuraminidase inhibitor susceptibility profile of pandemic and seasonal influenza viruses during the 2009-2010 and 2010-2011 influenza seasons in Japan. Antiviral Res 2013;99:261-9.

6. Moradi MT, Rafieian-Koupaei M, Shahrani M. The effect of garlic methanol extract on gastric acid and pepsin in basic and stimulated conditions by electrical stimulus of vagus nerve in rats. Life Sci J 2013;10:99-104.

7. Moradi MT, Karimi A, Alidadi S. In vitro antiproliferative and apoptosis-inducing activities of crude ethyle alcohole extract of Quercus brantii L. acorn and subsequent fractions. Chin J Nat Med 2016;14:196-202.

8. Mirhoseini M, Moradi MT, Asadi-Samani M. Traditionally used medicinal plants in the treatment of kidney stone: A review on ethnobotanical studies in Iran. Ambient Sci 2016;3:16-21. 
9. Parsaei P, Bahmani M, Karimi M, Naghdi N, Asadi-Samani M, Rafieian-Kopaei M. A review of analgesic medicinal plants in Iran. Der Pharm Lett 2016;8:43-51.

10. Kooti W, Ghasemiboroon M, Asadi-Samani M, Ahangarpoor A, Abadi MNA, Afrisham R, Dashti N. The effects of hydroalcoholic extract of celery on lipid profile of rats fed a high fat diet. Adv Environ Biol 2014;9:325-31.

11. Jivad N, Asadi-Samani M, Moradi M. The most important medicinal plants effective on migraine: A review of ethnobotanical studies in Iran. Der Pharm Chem 2016;8:4626.

12. Karimi A, Moradi MT, Alidadi S, Hashemi L. Anti-adenovirus activity, antioxidant potential, and phenolic content of black tea (Camellia sinensis Kuntze) extract. J Complement Integr Med 2016;13:357-63.

13. Karimi A, Rafieian-Kopaei M, Moradi MT, Alidadi S. AntiHerpes Simplex Virus Type-1 activity and phenolic content of crude ethanol extract and four corresponding fractions of Quercus brantii L Acorn. J Evid Based Complementary Altern Med 2017;22:455-61.

14. Moradi MT, Rafieian-Kopaei M, Karimi A. A review study on the effect of Iranian herbal medicine against in vitro replication of herpes simplex virus. Avicenna J Phytomed 2016;6:506-15.

15. Boiko YuA, Kravchenko IA, Shandra AA, Boiko IA. Extraction, identification and anti-inflammatory activity of carotenoids out of Capsicum anuum L. J Herbmed Pharmacol 2017;6:1015 .

16. Rafieian-Kopaei M, Shahinfard N, Rouhi-Boroujeni H, Gharipour M, Darvishzadeh-Boroujeni P. Effects of Ferulago angulata extract on serum lipids and lipid peroxidation. Evid Based Complement Alternat Med 2014;2014:680856.

17. Moon J-H, Terao J. Antioxidant activity of caffeic acid and dihydrocaffeic acid in lard and human low-density lipoprotein. J Agric Food Chem 1998;46:5062-5. 18.

18. Karimi A, Moradi M-T. Total phenolic compounds and in vitro antioxidant potential of crude methanol extract and the correspond fractions of Quercus brantii L. acorn. J Herbmed Pharmacol 2015;4:35-9.

19. Asadi-Samani M, Bahmani M, Rafieian-Kopaei M. The chemical composition, botanical characteristic and biological activities of Borago officinalis: A review. Asian Pac J Trop Med 2014;7:S22-S8.

20. Karimi A, Mohammadi-Kamalabadi M, Rafieian-Kopaei M, Amjad L, Salimzadeh L. Determination of antioxidant activity, phenolic contents and antiviral potential of methanol extract of Euphorbia spinidens Bornm (Euphorbiaceae). Trop J Pharm Res 2016;15:759-64.

21. Kim Y, Narayanan S, Chang KO. Inhibition of influenza virus replication by plant-derived isoquercetin. Antiviral Res 2010;88:227-35.

22. WHO, Manual for the Laboratory Diagnosis and Virological Surveillance of Influenza. Global Influenza Surveillance and Response System (GISRS) 2011. http://www.who.int/ influenza/gisrs_laboratory/manual_diagnosis_surveillance_ influenza/en/ (accessed May 18, 2016).

23. Reed LJ, Muench H. A simple method of estimating fifty per cent endpoints. Am J Epidemiol 1938;27:493-7.
24. Visintini Jaime MF, Redko F, Muschietti LV, Campos RH, Martino VS, Cavallaro LV. In vitro antiviral activity of plant extracts from Asteraceae medicinal plants. Virol J 2013;10:245.

25. Mosmann T. Rapid colorimetric assay for cellular growth and survival: Application to proliferation and cytotoxicity assays. J Immunol Methods 1983;65:55-63.

26. Rahnama S, Rabiei Z, Alibabaei Z, Mokhtari S, Rafieian-kopaei M, Deris F. Anti-amnesic activity of Citrus aurantium flowers extract against scopolamine-induced memory impairments in rats. Neurol Sci 2015;36:553-60.

27. Akhlaghi M, Shabanian G, Rafieian-Kopaei M, Parvin N, Saadat M, Akhlaghi M. Citrus aurantium blossom and preoperative anxiety. Rev Bras Anestesiol 2011;61:702-12.

28. Rabiei Z, Rafieian-kopaei M, Heidarian E, Saghaei E, Mokhtari S. Effects of Zizyphus jujube extract on memory and learning impairment induced by bilateral electric lesions of the nucleus basalis of Meynert in rat. Neurochem Res 2014;39:353-60.

29. Heidarian E, Rafieian-Kopaei M. Protective effect of artichoke (Cynara scolymus) leaf extract against lead toxicity in rat. Pharm Biol 2013;51:1104-9.

30. Mirhosseini M, Baradaran A, Rafieian-Kopaei M. Anethum graveolens and hyperlipidemia: A randomized clinical trial. J Res Med Sci 2014;19:758-61.

31. Taghikhani A, Afrough H, Ansari-Samani R, Shahinfard N, Rafieian-Kopaei M. Assessing the toxic effects of hydroalcoholic extract of Stachys lavandulifolia Vahl on rat's liver. Bratisl Med J 2014;115:121-4.

32. Shirzad H, Taji F, Rafieian-Kopaei M. Correlation Between antioxidant activity of garlic extracts and WEHI-164 Fibrosarcoma tumor growth in BALB/c mice. J Med Food 2011;14:969-74.

33. Rafieian-Kopaei M. In vitro evaluation of antioxidant properties of ten Iranian medicinal plants. Iran Red Crescent Med J 2014;16:e10264.

34. Reddy MK, Gupta SK, Jacob MR, Khan SI, Ferreira D. Antioxidant, antimalarial and antimicrobial activities of tannin-rich fractions, ellagitannins and phenolic acids from Punica granatum L. Planta Med 2007;73:461-7.

35. Mina CN, Farzaei MH, Gholamreza A. Medicinal properties of Peganum harmala L. in traditional Iranian medicine and modern phytotherapy: A review. J Tradit Chin Med 2015;35:104-9.

36. He J, Qi WB, Wang L, Tian J, Jiao PR, Liu GQ, Ye WC, Liao M. Amaryllidaceae alkaloids inhibit nuclear-to-cytoplasmic export of ribonucleoprotein (RNP) complex of highly pathogenic avian influenza virus H5N1. Influenza Other Respir Viruses 2013;7:922-31.

37. Zeng X, Dong Y, Sheng G, Dong X, Sun X, Fu J. Isolation and structure determination of anti-influenza component from Mahonia bealei. J Ethnopharmacol 2006;108:317-9.

38. Moradi MT, Karimi A, Lorigooini Z. Alkaloids as the natural anti-influenza virus agents: A systematic review. Toxin Rev 2017:1-8.

39. Lansky EP and Newman RA. Punica granatum (pomegranate) and its potential for prevention and treatment of inflammation and cancer. J Ethnopharmacol 2007; 109:177-206.

40. Shokri H, Sharifzadeh A. Zataria multiflora Boiss.: A review study on chemical composition, antifungal and anti-mycotoxin 
activities, and ultrastructural changes. J Herbmed Pharmacol 2017;6:1-9.

41. Sarrafchi A, Bahmani M, Shirzad H, Rafieian-Kopaei M. Oxidative stress and Parkinson's disease: New hopes in treatment with herbal antioxidants. Curr Pharm Des 2016; 22: $238-46$.

42. Rouhi-Boroujeni H, Heidarian E, Rouhi-Boroujeni H, Deris F, Rafieian-Kopaei M. Medicinal plants with multiple effects on cardiovascular diseases: a systematic review. Curr Pharm Des 2017; 23: 999 -1015.

43. Famouri F, Salehi MM, Rostampour N, Hashemi E, Shahsanaee A. The effect of silymarin on nonalcoholic fatty liver disease of children. J Herbmed Pharmacol 2017;6:16-20.

44. Shayganni E, Bahmani M, Asgary S, Rafieian-Kopaei M. Inflammaging and cardiovascular disease: Management by medicinal plants. Phytomedicine 2016;23:1119-26. 